\title{
The MHC Class II Transactivator CIITA: Not (Quite) the Odd-One-Out Anymore among NLR Proteins
}

\author{
Jorge Alfonso León Machado and Viktor Steimle *
}

Citation: León Machado, J.A.; Steimle, V. The MHC Class II Transactivator CIITA: Not (Quite) the Odd-One-Out Anymore among NLR Proteins. Int. J. Mol. Sci. 2021, 22, 1074. https://doi.org/10.3390/ ijms22031074

Received: 23 December 2020

Accepted: 19 January 2021

Published: 22 January 2021

Publisher's Note: MDPI stays neutral with regard to jurisdictional claims in published maps and institutional affiliations.

Copyright: (c) 2021 by the authors. Licensee MDPI, Basel, Switzerland. This article is an open access article distributed under the terms and conditions of the Creative Commons Attribution (CC BY) license (https:/ / creativecommons.org/licenses/by/ $4.0 /)$.
Département de Biologie, Université de Sherbrooke, 2500 Boul., Sherbrooke, QC J1K 2R1, Canada; jorge.alfonso.leon.machado@usherbrooke.ca

* Correspondence: viktor.steimle@usherbrooke.ca

\begin{abstract}
In this review, we discuss the major histocompatibility complex (MHC) class II transactivator (CIITA), which is the master regulator of MHC class II gene expression. CIITA is the founding member of the mammalian nucleotide-binding and leucine-rich-repeat (NLR) protein family but stood apart for a long time as the only transcriptional regulator. More recently, it was found that its closest homolog, NLRC5 (NLR protein caspase activation and recruitment domain (CARD)-containing 5), is a regulator of MHC-I gene expression. Both act as non-DNA-binding activators through multiple protein-protein interactions with an MHC enhanceosome complex that binds cooperatively to a highly conserved combinatorial cis-acting module. Thus, the regulation of MHC-II expression is regulated largely through the differential expression of CIITA. In addition to the well-defined role of CIITA in MHC-II GENE regulation, we will discuss several other aspects of CIITA functions, such as its role in cancer, its role as a viral restriction element contributing to intrinsic immunity, and lastly, its very recently discovered role as an inhibitor of Ebola and SARS-Cov-2 virus replication. We will briefly touch upon the recently discovered role of NLRP3 as a transcriptional regulator, which suggests that transcriptional regulation is, after all, not such an unusual feature for NLR proteins.
\end{abstract}

Keywords: CIITA; NLRC5; MHC genes; gene regulation

\section{Introduction}

The major histocompatibility complex (MHC; in humans, human leukocyte antigen, HLA) class I and class II molecules are antigen-presenting molecules for CD8+, and CD4+ T cells, respectively, and are therefore of crucial importance for the cellular immune response. Their expression is mainly controlled at the level of gene transcription. MHC-II genes show a highly controlled developmental, cell-type and stimulus-specific expression with constitutive expression confined to professional antigen-presenting cells (APCs) such as dendritic cells (DCs), B cells, macrophages, and thymic epithelial cells. Other cell types are negative; however, the expression can be induced in diverse cell types by different stimuli, most prominently IFN $\gamma$. The study of a rare severe combined primary immunodeficiency called the bare lymphocyte syndrome (BLS) led to the identification of class II transactivator (CIITA) and of the three genes coding for the subunits of the heterotrimeric RFX (regulatory factor X-box) complex binding to the X-box in the highly conserved W/SXY module found in all MHC-II gene promoters. CIITA has been recognized as the "master regulator" of MHC-II expression since the differential expression of MHC-II genes is largely due to the differential expression of CIITA. CIITA is a founding member of the NLR (nucleotidebinding and leucine-rich-repeat-containing) protein family, but for a long time, it stood apart in this protein family as the only transcriptional regulator. MHC-I genes, on the other hand, are expressed ubiquitously in nucleated cells; however, their expression levels differ widely, and they also show inducible expression, e.g., by IFN $\gamma$. In addition to other regulatory elements, the MHC-I gene promoter also contains a functional W/SXY element (also called site $\alpha$ ), and CIITA was found to contribute to MHC-I activation under certain 
conditions. However, it was also clear that many cell types express high levels of MHC-I in the complete absence of CIITA. This conundrum was resolved when it was recognized that the closest homolog of CIITA, NLRC5, functions as an MHC-I activator. In this review, we will mainly focus on CIITA but draw parallels to NLRC5 where appropriate.

\section{Identification of CIITA, the Master Regulator of MHC-II Expression}

CIITA was identified through a genetic complementation approach in the HLA-IInegative cell line RJ2.2.5, which was derived from the Burkitt lymphoma line Raji by $\gamma-$ irradiation followed by negative immunoselection [1,2]. The $4.5 \mathrm{~kb}$ cDNA coded for an 1130 amino acid protein, which was later identified as isoform III of CIITA (see below). CIITA mutations were identified in RJ2.2.5 and the B cell line BLS-2 from BLS complementation group A [2,3].

After the identification of CIITA, it was rapidly established that CIITA also controls IFN $\gamma$-induced MHC-II expression [4,5]. CIITA mRNA is induced by IFN $\gamma$, and ectopic expression of CIITA is necessary and sufficient to induce MHC-II gene expression [4,5]. This has since been repeated in many different cell lines. CIITA controls MHC-II expression quantitatively, and there is a close correlation between levels of CIITA and MHC-II mRNA expression levels in different tissues [6].

\section{CIITA, a Founding Member of Mammalian NLR Proteins}

CIITA is the founding member of the NLR protein family [7]. The nucleotide-binding domain also has been described as the NACHT (NAIP, CIITA, HET-E, TP1) domain and the protein family as the CATERPILLER (caspase activation and recruitment domain (CARD), transcription enhancer, $R$ (purine)-binding, pyrin, lots of leucine repeats) family [8-10]. CIITA was, however, for a very long time, the most exceptional member of this protein family in that it was the only transcriptional regulator.

The CIITA protein structure is characterized by an N-terminal acidic domain, a region rich in prolines, serines, and threonines (P/S/T domain), a central nucleotide-binding domain (GTP domain) and at least four C-terminal leucine-rich repeats (LRRs; Figure 1).

a) CIITA isoforms

\begin{tabular}{l|l|l|l|l|l|}
\hline F-I & CARD & AAD & P/S/T & NACHT & LRR (4) 1207 aa \\
F-III & AAD & P/S/T & NACHT & LRR (4) 1130 aa \\
\cline { 2 - 4 } & F-IV & AAD & P/S/T & NACHT & LRR (4) 1106 aa
\end{tabular}

\begin{tabular}{l|l|l|l|}
\hline b) NLRC5 & NACHT & LRR (26) \\
\hline
\end{tabular}

Figure 1. Domain structure of nucleotide-binding and leucine-rich-repeat (NLR) proteins CIITA (a), NLRC5 (b) and NLRP3 (c). Abbreviations: AAD, acidic activation domain; CARD, caspase activation and recruitment domain; DD, death domain; F-I, F-III, F-IV, isoforms-I, -III and -IV; LRR, leucine-rich repeats; NACHT, NAIP, CIITA, HET-E, TP1 domain; P/S/T, proline-serine-threonine rich domain; PYD, pyrin domain.

Three alternative promoters (pI, pIII, and pIV) and corresponding exons one generate three different isoforms of CIITA (isoforms I, III, and IV) differing in their N-termini. Isoform IV is initiated by an AUG in the common exon two, whereas isoforms I and III carry their own initiator AUGs leading to N-terminal extensions of 101 and 24 amino acids, respectively. The $\mathrm{N}$-terminal extension of isoform I shows homology to caspase activation and recruitment domain (CARD) and was found to increase MHC-II transcription somewhat [11] (Figure 1). 
While there is a close correlation between CIITA and MHC-II expression in many cell lines and tissues, there have nevertheless been many post-translational modifications described for CIITA. Modifications include phosphorylation, acetylation and deacetylation, and ubiquitination (reviewed in [12]). Furthermore, CIITA has been shown to self-associate via its GTP- and LRR-domains and also to oligomerize, contributing to nuclear localization (see also below) and transactivation [13-16].

CIITA has never been shown to bind directly to DNA and has therefore frequently been described as a coactivator, although the term is somewhat misleading since it is the principal activator of MHC-II expression. The N-terminal acidic domain of CIITA has been shown to function as a potent transactivation domain and shares many functionalities with the acidic domain of the viral activator VP16 [17-20]. CIITA activates transcription initiation and elongation through multiple mechanisms (reviewed in [21,22]). CIITA recruits components of the general transcription machinery, such as TFIID and TFIIB, it induces phosphorylation of RNA polymerase II and interacts with $P$-TEFb. It also recruits chromatin remodeling coactivators such as p300, CBP, PCAF, and BRG1 [21,22]. CIITA also has been shown to interact with the $19 \mathrm{~S}$ proteasomal subunit Sug1 [23,24]. CIITA also has been reported to have histone acetylase (HAT) activity, to possess an endogenous kinase activity, and can functionally replace the TFIID component TAF1 (reviewed in [25]) (Table 1).

Table 1. Features of the NLR proteins CIITA, NLRC5 and NLRP3.

\begin{tabular}{|c|c|c|c|}
\hline & CIITA & NLRC5 & NLRP3 \\
\hline Aliases & NLRA; C2TA; MHC2TA & NOD27; CLR16.1 & $\begin{array}{c}\text { CIAS1; PYPAF1; Cryopyrin; } \\
\text { CLR1.1; NALP3 }\end{array}$ \\
\hline Main functions & MHC-II gene transcription & $\begin{array}{c}\text { MHC-I gene transcription; } \\
\text { diverse roles in innate } \\
\text { immunity }\end{array}$ & $\begin{array}{c}\text { Inflammasome; } \\
\text { transcriptional regulator of } \\
\mathrm{T}_{\mathrm{H}} 2 \text { differentiation }\end{array}$ \\
\hline $\begin{array}{l}\text { Length } \\
\text { (human) }\end{array}$ & $\begin{array}{l}\text { FI: } 1207 \text { aa }^{\text {a }} \\
\text { FIII: } 1130 \text { aa } \\
\text { FIV: } 1106 \text { aa }\end{array}$ & 1886 aа & 1036 aа \\
\hline Subcellular localization & $\begin{array}{l}\text { Nuclear and cytoplasmic } \\
\text { Lb }^{\text {b}} \text { : nuclear }\end{array}$ & $\begin{array}{l}\text { Cytoplasmic } \\
\text { Lb: nuclear }\end{array}$ & $\begin{array}{l}\text { Nuclear and cytoplasmic } \\
\text { (in } \mathrm{T}_{\mathrm{H}} 2 \text { cells) }\end{array}$ \\
\hline Interaction partners ${ }^{c}$ & $\begin{array}{l}\text { RFX5; RFX-ANK; NF-YB; NF-YC; } \\
\text { CREB; Bob-1; p300; p400; PCAF; } \\
\text { CBP; BRG1; CARM1; TFIID; } \\
\text { TFIIB; P-TEFb; Sug1; SIRT1; } \\
\text { ZXDA; ZXDC }\end{array}$ & RFX-ANK & IRF4 \\
\hline
\end{tabular}

Footnotes: ${ }^{\mathrm{a}}$ : amino acids; ${ }^{\mathrm{b}}$ : leptomycin $\mathrm{B}$ treatment; ${ }^{\mathrm{c}}$ : only considering transcriptional regulatory functions.

Nucleo-cytoplasmic transport and localization of CIITA is a very complex subject with many different mutations distributed over the whole length of the protein affecting subcellular localization and transport. Both nuclear localization signals and nuclear export signals have been described, which may explain that wild-type CIITA shows a close to 50:50 distribution between nucleus and cytoplasm [15,26-32]. Several signals depend on post-translational modifications, such as the PCAF-dependent acetylation of lysines in the acidic domain [33]. Deletion of the acidic and P/S/T domains leads to an exclusively cytoplasmic CIITA fragment (L335), which can, however, be driven very efficiently to an exclusively nuclear localization by the addition of an SV40 large T nuclear localization signal (NLS-L335). Interestingly, both NLS-L335 and L335 are strongly dominant-negative, suggesting that essential interactions with protein partners can occur both in the nucleus and in the cytoplasm [31,34].

CIITA is a short-lived protein, with isoform III showing a half-life of about 30-45 min in pulse-chase experiments [35]. Degradation signals reside in the N-terminal P/S/T and acidic domains and in the extreme $\mathrm{N}$-terminus itself $[35,36]$. N-terminal epitope-tags stabilize the protein, and the first 10 amino acids of CIITA isoform III can destabilize a 
heterologous protein [36]. Interestingly, the transactivation potential is inversely correlated to stability, and CIITA isoform III interacts more efficiently with the RFX complex and the transcription machinery when compared to a truncated version [36]. Mono-ubiquitination was shown to increase CIITA-dependent MHC-II transactivation in a non-degradative manner [37].

\section{Identification of NLRC5 as an MHC-I Regulator}

NLRC5 was identified as an MHC-I regulator (also referred to as CITA; class I transactivator) through a knockdown approach by Kobayashi and colleagues [38]. This activity was mediated by the W/SXY motif and the MHC enhanceosome in the MHC-I promoters $[39,40]$. NLRC 5 and CIITA are the closest homologs among NLR proteins with respect to their GTP and LRR domains, but NLRC5 differs strongly from CIITA in the N-terminal domain $[38,41]$. There is no $\mathrm{P} / \mathrm{S} / \mathrm{T}$ region or acidic activation domain in NLRC5, but it rather carries $\mathrm{N}$-terminal to the GTP domain a region with weak homology to a CARD, which can potentially adopt a related death domain (DD) fold (Figure 1) ref. [42].

Domain swap experiments yielded very interesting information concerning the function of the NLRC5 DD [43]. NLRC5 exclusively activated an MHC-I reporter construct, whereas CIITA showed a strong preference for MHC-II in HEK293T cells [43]. It had been shown earlier that $\mathrm{N}$-terminal deletions of either the acidic $(\Delta-163)$ or the acidic and the P/S/T domain (L335) of CIITA lead to strong dominant-negative phenotypes [31,34]. Surprisingly, the fusion of the DD to $\Delta-163$ or to L335 led to constructs that were very efficient in activating both MHC-I and MHC-II genes [43]. This showed first that the DD could act as a bona fide transcriptional activation domain, and second, it demonstrated that the specificity for MHC-I or MHC-II promoters resulted from a combined action of the activation domains and the GTP- and LRR-domains. Finally, it revealed that under certain conditions, CIITA could be very efficiently recruited to MHC-I promoters.

NLRC5-deficient mice confirmed its importance for MHC-I expression, at least in certain cell subsets. While MHC-I expression was only mildly affected in APCs, such as macrophages, there was a strongly reduced MHC-I expression in lymphocytes such as T, NKT and NK cells [41,44-46].

\section{Cis-Acting Elements, MHC Enhanceosome, CIITA- and NLRC5-Cistromes}

The MHC-II promoter is the prototype of a composite regulatory element, which is often referred to as the W/SXY or SXY module. It is composed of four cis-acting elements, the $\mathrm{W} / \mathrm{S}, \mathrm{X}$ (or X1), $\mathrm{X} 2$ and $\mathrm{Y}$ boxes, which are present in classical and non-classical MHC-II gene promoters in a fixed order, orientation and spacing. The W/S element is bound by an as yet unknown factor, but the other three binding complexes have been well defined. The $\mathrm{X}$-box is bound by the heterotrimeric RFX (regulatory factor $\mathrm{X}$ ) complex composed of the DNA-binding subunit RFX5, RFX-AP (RFX-associated protein) and RFX-ANK or RFX-B (RFX-ankyrin-containing protein or RFX-defective in BLS group B). The corresponding genes are mutated in BLS complementation groups C, D and B, respectively [47-50]. The $\mathrm{X} 2$-element is bound by the cyclic-AMP-responsive-element-binding protein (CREB) [51], whereas the Y-box, which is an inverted CCAAT-element, is bound by the major CCAATbox-binding protein complex NF-Y $[52,53]$. These protein complexes bind cooperatively to the W/SXY module in vitro and in vivo and form a platform in the manner of an enhanceosome, to which CIITA is recruited through multiple protein-protein interactions [30,54-57]. Surprisingly, the W/SXY-binding complex is completely inert with respect to MHC-II activation in vivo, and it is only the recruitment of CIITA to the complex which is both necessary and sufficient to induce MHC-II expression (Figure 2). 


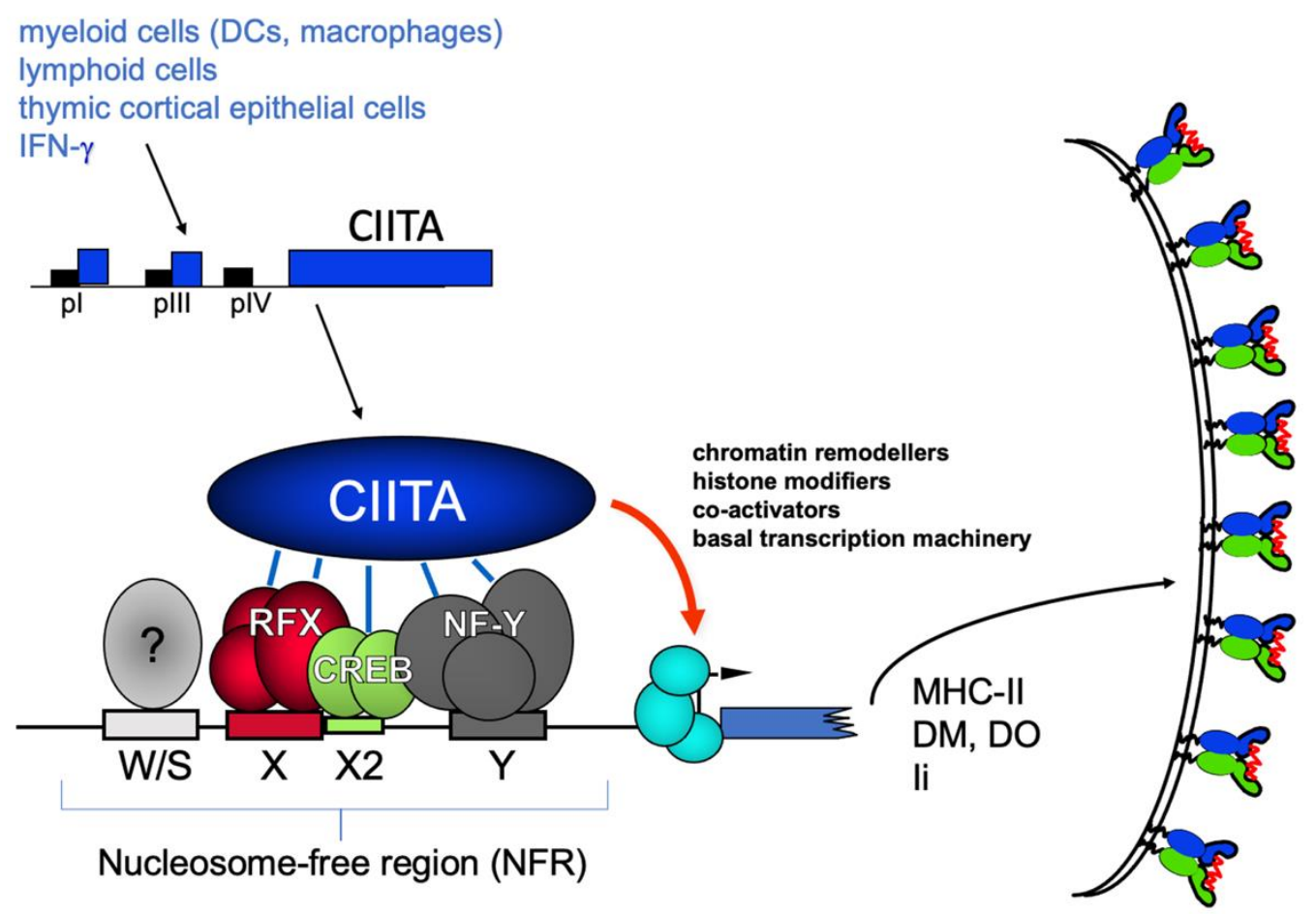

Figure 2. The master regulator CIITA and the major histocompatibility complex (MHC)-II enhanceosome.

Recently, the CCR4-NOT (carbon catabolite repressor 4-negative on TATA) complex has been implicated in the non-expression of MHC-II genes [58]. Knockdown or knock-out of CCR4-NOT subunits led to the expression of MHC-II genes in the absence of CIITA [58]. This suggests that the CCR4-NOT complex is necessary for the tightness of the regulation of MHC-II genes and to prevent leaky expression from MHC-II promoters in the absence of CIITA. CIITA must then, either directly or indirectly, relieve the suppression of CCR4NOT to activate MHC-II transcription. How this is achieved mechanistically is unknown at present.

CIITA induces transcription-associated histone modifications over the MHC-II promoter in two sequential phases, the first of which is characterized by a rapid increase in histone $\mathrm{H} 4$ acetylation over a large region. The second phase coincides with transcription and is restricted to short upstream regions, where histone acetylation and methylation occurs. This second phase is dependent on RNA pol-II-mediated transcription elongation [59]. Induction of CIITA by IFN $\gamma$ leads to the eviction of nucleosomes over the MHC-II promoters and the appearance of a nucleosome-free region (NFR) [60] (Figure 2).

The W/SXY module is found in the proximal promoters of all classical MHC-II genes (HLA-DR, -DQ and -DP) and also in several associated genes such as the invariant chain (Ii), HLA-DM and HLA-DO. In addition to these proximal promoter elements, more distal regulatory elements were identified throughout the MHC-II locus on human chromosome 6. These distal regulatory elements were identified based on their homology to either the MHC-II X-box (termed XL elements) or to the W/SXY motif. These elements bind RFX and CIITA in vivo and function as enhancers of MHC-II expression [61,62]. These elements are involved in long-distance interactions and help to achieve a coordinated and specific expression of MHC-II genes. Interestingly, several of these elements are bound by the CCCTC-binding factor CTCF, and knockdown of CTCF leads to a reduction of MHC-II gene expression concomitantly with a reduction in long-distance interactions $[22,63,64]$.

Recently, the region between the HLA-DRB1 and HLA-DQA1 loci in the MHC-II region was shown to display characteristics of a super-enhancer (SE) region $[65,66]$. Two SEs were identified in this region and termed DR/DQ-SE and XL9-SE, and were shown to be highly enriched in disease-associated SNPs. CRISPR/Cas9-mediated deletion of the DR/DQ-SE led to a reduction of HLA-DRB1 and HLA-DQA1 expression. Local chromatin 
interactions were disrupted by SE-deletions, suggesting that the SEs are involved in the organization of the local three-dimensional chromatin architecture [66].

Interestingly, the MHC-I gene promoters also possess a W/SXY module, which also has been described as site $\alpha$. However, the pattern of expression of MHC-I genes is only partly overlapping with that of MHC-II genes, and thus it is not surprising that MHC-I promoters also possess other regulatory elements implicated in constitutive and inducible expression. MHC-I genes are expressed ubiquitously, but their expression levels vary greatly with high levels of expression in hematopoietic cells. Furthermore, their expression can be modulated by different stimuli, prominently among them IFN $\gamma$. Somewhat surprisingly, it was found that CIITA can activate MHC-I expression, especially in cell lines that were very low or negative for MHC-I expression [67,68]. Expression was dependent on the presence of site $\alpha$ containing the W/SXY module and recruitment of the RFX complex [67-69]. On the other hand, CIITA KO mice and cells from BLS group A did not show a notable reduction in MHC-I expression and many cell lines express high levels of MHC-I in the complete absence of CIITA. This puzzle was at least partially resolved when NLRC5 was identified as an MHC-I activator and was shown to be recruited to the W/SXY module in the MHC-I promoters [38-40].

Analysis of the CIITA cistrome led to some very interesting results. A genome-wide scan for promoter-proximal-binding of CIITA via a ChIP-chip (chromatin IP-microarray) analysis yielded only nine validated targets in addition to MHC genes [70]. ChIP-seq analysis led to somewhat higher numbers of in vivo-binding sites with 843 or 480 hits, respectively [71,72]. However, this is still a very limited number of binding sites when compared to other transcription regulators that often show thousands of binding sites in the genome. Only a few novel genes in addition to MHC-II genes were found to be regulated by CIITA, and computational analysis showed that CIITA bound mostly through XY box motifs in one analysis [72], although the other study found that $60 \%$ of CIITA-binding sites were not associated with RFX5 binding [71]. The most astonishing results were, however, obtained in an NLRC5 ChIP-seq analysis, where only a highly restricted set of 12 targets in classical and non-classical MHC-I genes was identified [73]. NLRC5 and CIITA were found to have nonredundant target sets, although both were dependent on a W/SXY cis-acting module. Bioinformatic analysis revealed that the W/S element was essential in conferring the NLRC5 specificity [73]. The extremely restricted target gene set of NLRC5 is highly unusual and possibly unique among transcriptional regulators so far and illustrates the exquisite specificity that can be achieved through combinatorial cis-acting elements and cooperatively binding trans-acting factors.

\section{Regulation of CIITA Gene Expression}

As described above, the regulation of MHC-II gene expression is largely regulated through CIITA and levels of MHC-II, and CIITA mRNA expression correlate closely in various murine tissues and cell lines [6]. Thus, differential MHC-II expression is largely due to differential CIITA expression. Expression of CIITA appears to be mostly regulated at the level of transcription, although diverse post-transcriptional modifications of CIITA have also been described. Regulation of CIITA gene expression has been reviewed in some detail, and we will here sum up the most salient features, mainly based on studies of CIITA promoter knock-out mice [21,74]. Knock-out of promoter IV (pIV) of CIITA showed that this promoter was essential for the IFN $\gamma$-induced expression of CIITA in non-hematopoietic cells [75]. Macrophages, on the other hand, were shown to display normal IFN $\gamma$-induced CIITA and MHC-II expression in pIV KO mice [75]. A surprising finding was that pIV is essential for the expression of MHC-II in thymic cortical epithelial cells [76]. Consequently, CIITA pIV KO mice show a severe defect in the positive selection of CD4+ T cells [76]. Thus, CIITA pIV is essential for the CIITA—and ensuing MHC-II—expression in cells of non-hematopoietic origin [21,74].

The role of CIITA pIII expression was addressed through pIII + IV KO mice [77]. These mice lack CIITA and MHC-II expression in all B cell subsets, which is not the case in pIV 
KO mice [77]. Furthermore, CIITA and MHC-II expression were absent in plasmacytoid DCs (pDCs) [77], which possibly are of lymphoid origin rather than myeloid cells such as conventional DCs [78]. In contrast to their murine counterparts, human activated T cells express CIITA and MHC-II. It was shown that this activity is mediated by CIITA pIII [79]. Taken together, this indicates that CIITA pIII is specific for cells of lymphoid origin $[21,74]$.

CIITA pI was originally described as a DC-specific promoter [80]. It is also used for the constitutive and IFN $\gamma$-inducible expression of CIITA in macrophages and can thus be regarded as a myeloid-specific promoter [21,74]. Surprisingly, mice lacking CIITA pI and corresponding exon 1 had a relatively mild phenotype [81,82]. It was found that in pI KO animals, CIITA expression in DCs had shifted mainly to pIII. This suggested the involvement of distal regulatory elements in the expression of DC-specific CIITA and less tight insulation between $\mathrm{pI}$ and $\mathrm{pIII}$ compared to what had been found between $\mathrm{pIII}$ and pIV [81,82].

In addition to the proximal CIITA promoters, distal regulatory elements play a crucial role in CIITA expression. This has been best studied for IFN $\gamma$-induced expression of CIITA. Many distal regulatory elements involved in chromatin loops were identified from farupstream to downstream of the CIITA-gene locus [83]. The chromatin-remodeling enzyme BRG1 was found to be crucial for the induction of histone modifications and the recruitment of STAT1, IRF1 and p300 [83]. BRG1-dependency is conferred on the CIITA locus by the polycomb repressive complex 2 (PRC2) [84]. More recently, it was shown that NFAT5 binding to an upstream distal regulatory element is essential for the IFN $\gamma$-dependent, pI-mediated CIITA expression in macrophages [85].

\section{CIITA in Disease}

In order to evade the immune response, several pathogens have evolved different mechanisms to suppress the antigen presentation pathway. Several viruses such as HIV prevent this presentation both at the level of MHC-II genes and molecules and at the level of CIITA gene expression [86-89]. Inhibition of MHC-II expression by varicellazoster has also been observed $[90,91]$. Repression of CIITA by human cytomegalovirus (HCMV) and Epstein-Barr virus has also been shown [92-95]. Interference with the IFN $\gamma$ pathway has been observed in infections with influenza viruses [96,97]. Herpes viruses have been shown to simultaneously inhibit CIITA and interfere with the transport of MHC-II molecules [98]. Kaposi's sarcoma-associated herpes viruses have also been shown to inhibit transcription of CIITA via the viral protein vIRF3 and via SOCS3 $[99,100]$. Toxoplasma gondii downregulates CIITA and MHC-II in immune cells and neural cells by several different mechanisms [101-103]. Several species of Mycobacterium are capable of inhibiting CIITA via TLR-2 and chromatin modifications [104-106]. Chlamydia infection inhibits MHC-II expression via two different cell type-specific mechanisms, one chlamydial protease-like activity factor (CPAF)-independent and MyD88-dependent in bone marrowderived macrophages and one CPAF-dependent in mouse embryonic fibroblasts $[107,108]$.

Modulation of antigen presentation during viral infections is an important phenomenon, as inhibition of this pathway facilitates the spreading of the virus. HCMV has been shown to modulate several antiviral responses, including downregulation of MHC-I expression to inhibit CD8+ T cell activity [109,110]. However, certain viral effects on the CD4+ branch of immunity are not as well understood, mainly due to the absence of proper cellular models for the endogenous expression of MHC-II. Nevertheless, recent studies on the Kasumi-3 cell line were able to show that endogenous MHC-II downregulation by HCMV was mediated by inhibition of CIITA expression. This inhibition was also independent of previously known viral MHC-II repressor proteins that intervene in the IFN $\gamma$-induced expression, such as the tegument protein pp65, the viral IL-10 homolog, and two proteins coded from unique short (US) regions, US2 and US3, failed to downregulate MHC-II expression. Single gene knock-out studies failed to find a responsible gene in the US region, thus suggesting that the cause may be a complex interaction of several proteins in this region or that the responsible factor is coded elsewhere [95]. 
The Epstein-Barr virus is also known to evade the immune response by inhibiting CIITA. Expression of the immediate-early protein Zta in Raji cells has been shown to inhibit the expression of CIITA. This inhibition is mediated by Zta at the transcriptional level. Analysis of CIITA pIII revealed the existence of two Zta response elements (ZRE) in its sequence. The binding of Zta to these ZREs prevents transcription of CIITA and thus leads to inhibition of MHC-II expression [111].

\section{CIITA-Dependent Regulation of Genes Other Than MHC-Genes}

Children suffering from BLS never showed a phenotype that could not be explained by the absence of MHC-gene expression, indicating that CIITA and the three genes encoding RFX-subunits have an exquisite specificity for MHC genes. Given what we know about gene-regulation in general, it is, however, not astonishing that there are a limited number of other genes that appear to be regulated by CIITA, frequently in an RFX-dependent manner. A few genes possess well-defined W/SXY modules in their regulatory regions and are at least partially regulated by CIITA and RFX. Examples are the semaphorin receptor plexinA1, RAB4B and butyrophilin-2A2 (BTN2A2) [112-114]. A certain number of genes have been reported to be negatively regulated by CIITA in IFN $\gamma$-induced cells. The best-studied example is probably collagen (COL1A2), where IFN $\gamma$-induced CIITA inhibits transcription in an RFX-dependent manner [115-120]. CIITA-mediated inhibition was dependent on the presence of the N-terminal acidic and P/S/T domains [116]. Recently, IFN $\gamma$-induced CIITA was shown to repress eNOS via the recruitment of the histone H3K9 trimethyl transferase SUV39H1 [121]. While it thus appears that CIITA-mediated inhibition is at least in part executed via the recruitment of co-repressors, it is not clear how the decision between activation and inhibition is made mechanistically. Some other genes have been proposed to be coregulated positively or negatively by CIITA (see discussion in $[21,74]$ ), but several of them could not be confirmed in vivo [122]. Taken together, it is apparent that CIITA is a highly dedicated and specific regulator of the MHC-II antigen presentation pathway.

\section{Three's a Crowd: NLRP3 as a $\mathbf{T}_{\mathrm{H}} \mathbf{2}$ Transcriptional Activator}

Bruchard and colleagues reported that NLRP3, a well-known component of an inflammasome complex, can act as a transcriptional activator in $\mathrm{CD} 4+\mathrm{T}_{\mathrm{H}} 2$ cells, contributing to the expression of $\mathrm{T}_{\mathrm{H}} 2$ cytokines, such as IL-4, IL-5, and IL-13 [123,124] (Figure 1). NLRP3 is normally cytoplasmic but was found to be localized in the nucleus of $\mathrm{T}_{\mathrm{H}} 2$ cells [123] (Table 1). Activation of the Il4 promoter occurred through interaction with IRF4. Similar results have recently been found in macrophages [125]. NLRP3 carries a pyrin domain in its N-terminus; however, the mechanism by which NLRP3 activates transcription was not investigated [123]. These results indicate that a third NLR protein can act as a transcriptional activator and raise the question of whether the same may apply to yet other members of this versatile protein family.

\section{CIITA and Cancer}

\subsection{CIITA and Immune Evasion in Cancer}

Given its function as a transcription factor regulating the expression of MHC-II genes, CIITA has been shown to play important roles in different pathologies. One of the most prominent examples of cancers where CIITA inactivation participates in tumor proliferation is the primary mediastinal large B-cell lymphoma (PMLBCL). This cancer is an aggressive form of non-Hodgkin's lymphoma that often originates in the mediastinum, probably of thymic medullary B-cell origin [126]. These tumors present frequent genomic alterations in CIITA, comprising structural genomic rearrangements, missense, nonsense, and frameshift mutations found in 53\% of primary tumor biopsies and PMBCL-derived cell lines [127]. Such alterations were also observed in an analysis of public data sets of whole transcriptome sequencing (RNA-seq) from three PMLBCL-derived cell lines: Karpas1106P, MedB-1, and U2940 [128]. Characterization of the CIITA-mutations in MedB-1 revealed two missense mutations (in trans) causing amino acid exchange in the acidic domain and 
the NACHT domain. Mutations in Karpas1106P presented two important deletions in both chromosomes; in one case, CIITA and the downstream SOCS1 gene are completely eliminated, while the other one results in disruption of CIITA. The cell line U2940 also presents an important deletion in one allele that generates a fusion of the upstream NUBP1 gene and CIITA, producing a fused transcript; the second allele contains a point mutation that generates a stop codon. In all cases, these modifications prevented the expression of the MHC-II genes and presumably helped the immune escape of the tumor [127]. These genetic modifications are so prevalent that their gene expression profile (GEP) can be used as a pattern for the identification of diffuse large B-cell lymphomas (DLBCL) without mediastinal participation that shows PMLBCL characteristics [129]. However, the immune escape phenomenon by PMBL is not only due to the inactivation of CIITA, as an integrative genomic analysis identified mutations in the Janus kinase-signal transducer and activator of transcription (JAK-STAT) and the nuclear factor $\mathrm{\kappa B}(\mathrm{NF} \kappa \mathrm{B})$ pathways as concomitant factors participating to the immune escape [130].

Similar observations were made in cutaneous DLBCL. Analysis of 37 samples revealed that mutations that inhibit antigen presentation were second only to alterations in the NFKB pathway. Predictably, most of these mutations were present in B2M, CIITA and HLA genes [131]. Similar types of alterations have also been identified in a group of 20 patients suffering from primary cutaneous diffuse large B-cell lymphoma leg-type (PCLBCL-LT). Next-generation sequencing using a lymphoma panel for diffuse large B-cell lymphomas revealed frequent genetic losses in CIITA, as in previous cases, this loss may participate in the immune escape [132].

An important factor regulating the MHC-II expression in some blood cancers is Forkhead box P1 (FOXP1) [133]. This transcription factor has been observed as a poor prognosis marker in DLBCLs. Using microarray analysis of siRNA FOXP1-silenced DLBCL cell lines, differential regulation of MHC-II expression was identified between DLBCL expressing wild-type FOXP1 and activated-B-cell-like DLBCL, which expresses short isoforms of FOXP1. The cause of the downregulation of MHC-II was suggested to be FOXP1 acting as a novel negative regulator of CIITA target genes; thus, suppression of FOXP1 could represent a therapeutic target for the treatment of DLBCL [133]. Another factor involved in the expression of CIITA in cancer has been identified in pediatric glioblastomas. RACK7, a receptor for activated C-kinase, acts as an inhibitor of CIITA. RACK 7 recognizes a point mutation on histone H3.3 (H3.3G34R), often found in this type of tumor. Binding by RACK7 modifies the chromatin environment and suppresses the expression of CIITA, and thus limits the immunogenicity of the tumor [134].

Chronic myeloid leukemia (CML) is another type of blood cancer presenting CIITA aberrations important for the prognosis of the condition. It has been reported that MHCII and CIITA are greatly downregulated in CML cases; however, the expression was increased following stimulation by IFN $\gamma$, thus proving that the MHC-II pathways remained functional [135]. Interestingly, expression of MHC-II and CIITA was significantly increased by inhibition of JAK1/2 via ruxolitinib. These results suggest that cytokine induction of the JAK-mediated pathway antagonizes MHC-II expression, thus presenting the opportunity for new therapeutic targets for the treatment of CML [135].

A strong downregulation of CIITA has been reported in blasts from acute myeloid leukemia (AML) relapse cases following allogeneic transplantation of hematopoietic cells. Inhibition of CIITA expression was concomitant with the upregulation of inhibitory checkpoint molecules that prevented T-cell recognition of AML cells and facilitated relapse [136].

Some cancers with viral infections have been shown to present upregulated expression of MHC-II. For example, Epstein-Barr virus-associated gastric adenocarcinomas (EBVaGC) presented a better outcome than EBV-negative cancers of the same type. The effect is suggested to be a consequence of upregulation of MHC-II expression that is concomitant with the expression of foreign viral antigens. Using RNA-seq data from 400 gastric cancer patients, the upregulation of all MHC-II involved genes, including CIITA and RFX5, was observed compared to normal tissues or other types of gastric cancers [137]. Expression 
of these genes was unexpected, as EBV infection induces expression of the viral protein BZLF1 (ZEBRA, Zta), which represses transcription of CIITA [111,138]. While expression of the viral protein was still found in many of these cancers, upregulation of MHC-II was correlated with higher levels of intratumoral IFN $\gamma$. These results suggested an APC function of cancer cells, increasing the immunogenicity of the tumor microenvironment and thus helping cancer elimination [137].

Another example of cancers where viral modulation of the MHC-II expression plays an important role is head and neck squamous cell carcinomas (HNSCC) [139]. A subset of these cancers is induced by high-risk human papillomaviruses (HPV) infections. Analysis of more than 500 RNA-seq data sets from HNSCC patients allowed the identification of the impact of HPV infections on the MHC-II expression and regulation. Upregulation of all genes involved in MHC-II antigen presentation roles was observed in HPV-positive cases compared to HPV-negative controls; among these genes were CIITA and RFX5 [139]. Similar to the observations of Ghasemi and colleagues, a viral infection of tumoral bodies was correlated with higher levels of IFN $\gamma$. This case also suggests an APC role for the cancer cells that participate in tumor elimination $[137,139]$.

\subsection{Generation of Cancer Vaccines via CIITA and NLRC5}

The evident problem presented by the immune escape of tumors via suppression of antigen presentation has prompted some scientists to try to increase the immunogenicity of the cancer cells by artificially increasing the expression of the antigen-presenting pathways via the ectopic expression of CIITA or NLRC5.

The direct role of cancer cells as APCs has been investigated using a model of transgenic mice, the CD11c.DTR C57BL/6 mice $\left(\mathrm{H}-2^{\mathrm{b}}\right)$, where the dendritic cells (DC) can be functionally deleted via diphtheria toxin [140]. In order to eliminate other potential professional APCs, macrophages were also eliminated via the administration of liposome clodronate. In these mice, the H-2 ${ }^{\mathrm{d}}$ cells (epithelial cancers) were stably transfected with a plasmid carrying CIITA. Increased immunogenicity by the MHC-II expressing cells was able to successfully prime CD4+ T-cells and induce an antitumoral immune response in the absence of natural APCs [140]. From these observations, it has been proposed that antigens presented by MHC-II molecules and the induction of a Thelper response could present a promising option to elicit an antitumor response that may even be more efficient than stimulating the MHC-I pathway [141].

Several studies have shown that artificial overexpression of CIITA, and thus of MHCII, in cancer cells leads to increased antitumoral response. It has been shown that this expression significantly alters the tumor microenvironment by replacing a low population of tumor-infiltrating macrophages and neutrophils with activated CD4+ and CD8+ Tcells [141]. Using high MHC-II expressing cells, it has been possible to purify and isolate MHC-II bound peptides [142]. Application of this protocol to human hepatocarcinoma for the isolation of specific tumor peptides from both MHC-I and MHC-II pathways allowed the creation of the first multi-epitope, multi-target, and multi-allele vaccine targeting activation of CD4+ and CD8+ T cells. This vaccine was undergoing phase I/II clinical trials as of 2019, results from these trials should soon provide insights into the efficiency and safety of this method [141].

An important recent observation was made by Johnson and colleagues concerning the participation of MHC-II expression in anti-PD-1 therapies [143]. Two orthotopic immunocompetent murine models of non-small cell lung cancer, the cell line CMT167, which is sensitive to anti-PD1 therapy and the Lewis lung carcinoma (LLC), which is resistant, were used. RNA-seq analysis from in vivo samples of these cell lines revealed that sensitivity to the therapy was dependent on the CIITA-mediated expression of tumor-cell-specific MHCII. Ectopic expression of CIITA in LLC rendered these cells MHC-II-positive and sensitized the tumors to anti-PD-1 therapy. Upregulation of CIITA was also associated with increased T-cell infiltration and a survival benefit in patient-derived lung adenocarcinomas [143]. 
Similarly, targeting the activation of the MHC-I pathways also has been explored. Activation of NLRC5 induces stimulation of the antigen processing machinery (APM) and expression of MHC-I molecules [38-40,144]. Importantly, it has been shown that inhibition of the expression of NLRC5 induced by promoter methylation, loss of copy number and somatic mutations induces strong downregulation of MHC-I, and the level of MHC-I expression is an important marker for the prognosis of the majority of solid cancers $[145,146]$. This suggested that ectopic expression of NLRC5 may be of therapeutic benefit. Stable transfection of NLRC5 into the murine melanoma cell line B16-F10 resulted in the upregulation of MHC-I molecules, TAP1, LMP2 and LMP7 (large multifunctional proteasome 2 and 7) [147]. This activation of the general APM leads to an efficient presentation of the tumoral antigen gp100 and subsequent activation of CD8+ T-cells specific for gp100. Injection of B16-F10 expressing NLRC5 (B16-5) in murine models showed efficient activation of the antitumoral immune response dependent on MHC-I expression. This immunity was translated into the reduced formation of tumor foci in the lungs and skin. Very interestingly, injection of irradiated B16-5 cells led to immunization against the parental cell line B16, which expresses very low levels of MHC-I molecules [147]. These results show the importance of both antigen-presenting pathways, not only in the antitumoral immunity but as possible targets for therapeutic treatments.

\section{CIITA and Viral Inhibition}

\subsection{CIITA as a Viral Restriction Factor}

An activity of CIITA that goes beyond its transcriptional regulatory function is its ability to act as an antiviral restriction factor (RF). Viral RFs are a relatively recent discovery and are part of a new branch of the immune system known as intrinsic immunity [148]. This mechanism acts by restricting viral replication and assembly of new viral particles and is mediated by proteins often expressed in a constitutive manner; however, some can also be induced by a viral infection. The most significant activity of restriction factors, when compared to other antiviral responses, is their ability to act immediately, thus being important factors in diminishing the effectiveness of the infection in early stages [148]. CIITA has been observed to behave as a restriction factor for human $\mathrm{T}$ cell leukemia virus-1 (HTLV-1), Human T cell leukemia virus-2 (HTLV-2) and human immunodeficiency virus-1 (HIV-1) [149-151]. CIITA was first shown as an RF against HIV-1 in T cells, where it competes for binding to cyclin-T1 (CyT1), a subunit of the $P$-TEFb complex, with the viral transactivator Tat $[86,87]$. Further studies on myeloid cells, another target of HIV-1, were performed in the promonocytic cell line U937, using mutants that allowed infection (U937 Plus) or not (U937 Minus) [152]. Comparing the differential expression of CIITA in these cell lines, these studies presented evidence that CIITA was able to suppress replication of HIV-1 by inhibiting transactivation of Tat, thus positioning CIITA as a general RF in myeloid cells as well as T cells [152,153]. This antiviral activity was observed to be independent of the activity of tripartite motif 22 (TRIM22), another RF that was identified before CIITA as an inhibitor of HIV-1 transcription [154]. Nevertheless, evidence suggests that TRIM22 and CIITA cooperate in their RF activity. This cooperation is mediated by the assembly of a nuclear body, a protein complex containing CIITA, TRIM22 and the promyelocytic leukemia protein (PML) [155]. The nuclear bodies then compete for and capture CyT1, thus preventing the activation of Tat. This mechanism constitutes the first example of synergistic activity in intrinsic immunity [155].

The activity of CIITA as an RF for HTLV-1 is mediated by a direct interaction between CIITA and the viral protein Tax-1. This binding prevents the interaction of Tax-1 with its coactivators $\mathrm{p} 300 / \mathrm{CBP}$-associated factor (PCAF), the cyclic AMP-responsive elementbinding protein (CREB), and the activating transcription factor-1 (ATF1), which are required for the proper activation of HTLV-1 [150]. This mechanism also has been shown to participate in CIITA's inhibition of HTLV-1 induced oncogenic transformation of T cells. This transformation is induced by persistent activation of the NF- $\mathrm{kB}$ pathway mediated by Tax-1. Interestingly, CIITA has been observed to inhibit the NF- $\mathrm{kB}$ pathway via several 
mechanisms; the interaction between CIITA and Tax-1 in the cytoplasm prevents activation and nuclear transport of p50/RelA/IkB complexes, while nuclear bodies containing CIITA bind Tax-1/RelA and block activation of NF- $\mathrm{B}$ controlled genes [153]. As mentioned before, CIITA is also able to act as an RF for HTLV-2, similar to the mechanism observed for HTLV-1. CIITA interacts directly and inhibits the activity of the Tax-2 transactivator. However, the domains that interact between CIITA and both Tax proteins are different, but overlapping in each case; for Tax-1, CIITA interacts via two adjacent regions comprising amino acids 1 to 252 and 253 to 410, while the interaction with Tax-2 is mediated by the $\mathrm{N}$-terminal domain between amino acids 1 to 321 and seems to act in cooperation with NFY [156].

\subsection{CIITA as an Inhibitor of Ebola and Corona Viruses}

Recently, Bruchez and colleagues showed that CIITA inhibited the Ebola virus and coronaviruses, although CIITA was acting in this instance as a conventional MHC-II gene activator and not as a viral restriction factor [157]. With the objective of identifying pathways that participate in resistance mechanisms to viral infections, a transposon-mutagenesis forward screen in U2OS cells was applied. Transposon-modified cellular libraries were treated with vesicular stomatitis virus expressing the Ebola glycoprotein (EboGP-VSV), and cells surviving the infection were expanded and analyzed by next-generation sequencing of the transposon insertion sites. In addition to the Ebola virus receptor NPC1, only CIITA was identified repeatedly as a transposon target. Transposon insertion resulted in the upregulation of CIITA, which increased the cellular resistance to EboGP-VSV between 100 and 1000-fold. Further experiments suggested that CIITA inhibits viral entry by blocking fusion in the endosomes. Given that CIITA acts as a transcription factor, genes controlled by CIITA were analyzed. Among these, only the isoform p41 of CD74, the invariant chain of the MHC-II molecules, was able to induce viral resistance. Expression of CD74 fragments pinpointed the resistance ability to the thyroglobulin domain, whose presence in the endosome inhibits the activity of cathepsins, which are needed for the processing of the EboGP and subsequent viral fusion. Similar glycoprotein processing is needed for the insertion of other viruses, such as coronaviruses. Expression of p41-CD74 in U2OS and Vero cells was able to block entry of pseudotyped viruses expressing the S protein from SARS-CoV-2 and WIV1-CoV, thus confirming that p41-CD74 inhibited processing of the viral protein. These experiments were important for the identification of new mechanisms dependent on CIITA that are astonishingly separated from the antigen-presenting pathways. These experiments also suggest that there may be novel and important functionalities for CIITA left to identify [157].

\section{Conclusions}

In this review, we have attempted to give an overview of the biology of CIITA, the master regulator of MHC-II expression. CIITA and its closest homolog NLRC5 are highly dedicated regulators of MHC-gene expression and are therefore of crucial importance for the regulation of the cellular immune response. Differential expression of MHC-II gene expression is mediated by the differential expression of CIITA, which is controlled by three independent promoters. As could be expected, CIITA is a major target for cancer immune escape mechanisms, and ectopic expression of CIITA and NLRC5 present promising avenues in cancer vaccination strategies. Finally, CIITA acts as a viral inhibitor, both as a viral restriction factor and through its role as an MHC-II gene regulator, demonstrating its crucial role for the immune response.

Author Contributions: J.A.L.M. and V.S. conceived, wrote and reviewed the manuscript. All authors have read and agreed to the published version of the manuscript.

Funding: This research was funded by NSERC, grant number RGPIN-2016-05455.

Conflicts of Interest: The authors declare no conflict of interest. The funders had no role in the writing of the manuscript. 


\section{References}

1. Accolla, R.S. Human B cell variants immunoselected against a single Ia antigen subset have lost expression of several Ia antigen subsets. J. Exp. Med. 1983, 157, 1053-1058. [CrossRef] [PubMed]

2. Steimle, V.; Otten, L.A.; Zufferey, M.; Mach, B. Complementation cloning of an MHC class II transactivator mutated in hereditary MHC class II deficiency (or bare lymphocyte syndrome). Cell 1993, 75, 135-146. [CrossRef]

3. Brown, J.A.; He, X.F.; Westerheide, S.D.; Boss, J.M. Characterization of the expressed CIITA allele in the class II MHC transcriptional mutant RJ2.2.5. Immunogenetics 1996, 43, 88-91. [CrossRef] [PubMed]

4. Steimle, V.; Siegrist, C.A.; Mottet, A.; Lisowska-Grospierre, B.; Mach, B. Regulation of MHC class II expression by interferongamma mediated by the transactivator gene CIITA. Science 1994, 265, 106-109. [CrossRef] [PubMed]

5. Chang, C.H.; Fontes, J.D.; Peterlin, M.; Flavell, R.A. Class II transactivator (CIITA) is sufficient for the inducible expression of major histocompatibility complex class II genes. J. Exp. Med. 1994, 180, 1367-1374. [CrossRef] [PubMed]

6. Otten, L.A.; Steimle, V.; Bontron, S.; Mach, B. Quantitative control of MHC class II expression by the transactivator CIITA. Eur. J. Immunol. 1998, 28, 473-478. [CrossRef]

7. Ting, J.P.; Lovering, R.C.; Alnemri, E.S.; Bertin, J.; Boss, J.M.; Davis, B.K.; Flavell, R.A.; Girardin, S.E.; Godzik, A.; Harton, J.A.; et al. The NLR gene family: A standard nomenclature. Immunity 2008, 28, 285-287. [CrossRef]

8. Koonin, E.V.; Aravind, L. The NACHT family-a new group of predicted NTPases implicated in apoptosis and MHC transcription activation. Trends Biochem. Sci. 2000, 25, 223-224. [CrossRef]

9. Ting, J.P.; Davis, B.K. CATERPILLER: A novel gene family important in immunity, cell death, and diseases. Annu. Rev. Immunol. 2005, 23, 387-414. [CrossRef]

10. Ting, J.P.; Williams, K.L. The CATERPILLER family: An ancient family of immune/apoptotic proteins. Clin. Immunol. 2005, 115, 33-37. [CrossRef]

11. Nickerson, K.; Sisk, T.J.; Inohara, N.; Yee, C.S.; Kennell, J.; Cho, M.C.; Yannie, P.J., 2nd; Nunez, G.; Chang, C.H. Dendritic cell-specific MHC class II transactivator contains a caspase recruitment domain that confers potent transactivation activity. J. Biol. Chem. 2001, 276, 19089-19093. [CrossRef] [PubMed]

12. Wu, X.; Kong, X.; Luchsinger, L.; Smith, B.D.; Xu, Y. Regulating the activity of class II transactivator by posttranslational modifications: Exploring the possibilities. Mol. Cell. Biol. 2009, 29, 5639-5644. [CrossRef] [PubMed]

13. Linhoff, M.W.; Harton, J.A.; Cressman, D.E.; Martin, B.K.; Ting, J.P. Two distinct domains within CIITA mediate self-association: Involvement of the GTP-binding and leucine-rich repeat domains. Mol. Cell. Biol. 2001, 21, 3001-3011. [CrossRef] [PubMed]

14. Sisk, T.J.; Roys, S.; Chang, C.H. Self-association of CIITA and its transactivation potential. Mol. Cell. Biol. 2001, 21, 4919-4928. [CrossRef] [PubMed]

15. Kretsovali, A.; Spilianakis, C.; Dimakopoulos, A.; Makatounakis, T.; Papamatheakis, J. Self-association of CIITA correlates with its intracellular localization and transactivaiton. J. Biol. Chem. 2001, 18, 18.

16. Tosi, G.; Jabrane-Ferrat, N.; Peterlin, B.M. Phosphorylation of CIITA directs its oligomerization, accumulation and increased activity on MHCII promoters. EMBO J. 2002, 21, 5467-5476. [CrossRef] [PubMed]

17. Riley, J.L.; Westerheide, S.D.; Price, J.A.; Brown, J.A.; Boss, J.M. Activation of class II MHC genes requires both the X box region and the class II transactivator (CIITA). Immunity 1995, 2, 533-543. [CrossRef]

18. Zhou, H.; Glimcher, L.H. Human MHC class II gene transcription directed by the carboxyl terminus of CIITA, one of the defective genes in type II MHC combined immune deficiency. Immunity 1995, 2, 545-553. [CrossRef]

19. Fontes, J.D.; Jiang, B.; Peterlin, B.M. The class II trans-activator CIITA interacts with the TBP-associated factor TAFII32. Nucleic Acids Res. 1997, 25, 2522-2528. [CrossRef]

20. Mahanta, S.K.; Scholl, T.; Yang, F.C.; Strominger, J.L. Transactivation by CIITA, the type II bare lymphocyte syndrome-associated factor, requires participation of multiple regions of the TATA box binding protein. Proc. Natl. Acad. Sci. USA 1997, 94, 6324-6329. [CrossRef]

21. Reith, W.; LeibundGut-Landmann, S.; Waldburger, J.M. Regulation of MHC class II gene expression by the class II transactivator. Nat. Rev. Immunol. 2005, 5, 793-806. [CrossRef] [PubMed]

22. Choi, N.M.; Majumder, P.; Boss, J.M. Regulation of major histocompatibility complex class II genes. Curr. Opin. Immunol. 2011, 23, 81-87. [CrossRef] [PubMed]

23. Bhat, K.P.; Turner, J.D.; Myers, S.E.; Cape, A.D.; Ting, J.P.; Greer, S.F. The 19S proteasome ATPase Sug1 plays a critical role in regulating MHC class II transcription. Mol. Immunol. 2008, 45, 2214-2224. [CrossRef] [PubMed]

24. Bhat, K.P.; Truax, A.D.; Brooks, J.K.; Greer, S.F. Association of the 195 proteasomal ATPases with the ATPase-binding domain of CIITA is essential for CIITA stability and MHC class II expression. Immunol. Cell Biol. 2010, 88, 807-816. [CrossRef] [PubMed]

25. Devaiah, B.N.; Singer, D.S. CIITA and Its Dual Roles in MHC Gene Transcription. Front. Immunol. 2013, 4, 476. [CrossRef]

26. Harton, J.A.; Cressman, D.E.; Chin, K.C.; Der, C.J.; Ting, J.P. GTP binding by class II transactivator: Role in nuclear import. Science 1999, 285, 1402-1405. [CrossRef]

27. Harton, J.A.; O'Connor, W., Jr.; Conti, B.J.; Linhoff, M.W.; Ting, J.P. Leucine-rich repeats of the class II transactivator control its rate of nuclear accumulation. Hum. Immunol. 2002, 63, 588-601. [CrossRef]

28. Cressman, D.E.; Chin, K.C.; Taxman, D.J.; Ting, J.P. A defect in the nuclear translocation of CIITA causes a form of type II bare lymphocyte syndrome. Immunity 1999, 10, 163-171. [CrossRef] 
29. Cressman, D.E.; O'Connor, W.J.; Greer, S.F.; Zhu, X.S.; Ting, J.P. Mechanisms of nuclear import and export that control the subcellular localization of class II transactivator. J. Immunol. 2001, 167, 3626-3634. [CrossRef]

30. Hake, S.B.; Masternak, K.; Kammerbauer, C.; Janzen, C.; Reith, W.; Steimle, V. CIITA leucine rich repeats control nuclear localisation, in vivo recruitment to the MHC class II enhanceosome, and MHC class II gene transactivation. Mol. Cell. Biol. 2000, 20, 7716-7725. [CrossRef]

31. Camacho-Carvajal, M.M.; Klingler, S.; Schnappauf, F.; Hake, S.B.; Steimle, V. Importance of class II transactivator leucine-rich repeats for dominant-negative function and nucleo-cytoplasmic transport. Int. Immunol. 2004, 16, 65-75. [CrossRef]

32. Chiu, E.; Gold, T.; Fettig, V.; LeVasseur, M.T.; Cressman, D.E. Identification of a nuclear export sequence in the MHC CIITA. J. Immunol. 2015, 194, 6102-6111. [CrossRef]

33. Spilianakis, C.; Papamatheakis, J.; Kretsovali, A. Acetylation by PCAF enhances CIITA nuclear accumulation and transactivation of major histocompatibility complex class II genes. Mol. Cell. Biol. 2000, 20, 8489-8498. [CrossRef]

34. Bontron, S.; Ucla, C.; Mach, B.; Steimle, V. Efficient repression of endogenous major histocompatibility complex class II expression through dominant negative CIITA mutants isolated by a functional selection strategy. Mol. Cell. Biol. 1997, 17, 4249-4258. [CrossRef]

35. Schnappauf, F.; Hake, S.B.; Camacho Carvajal, M.M.; Bontron, S.; Lisowska-Grospierre, B.; Steimle, V. N-terminal destruction signals lead to rapid degradation of the major histocompatibility complex class II transactivator CIITA. Eur. J. Immunol. 2003, 33, 2337-2347. [CrossRef]

36. Beaulieu, Y.B.; Leon Machado, J.A.; Ethier, S.; Gaudreau, L.; Steimle, V. Degradation, Promoter Recruitment and Transactivation Mediated by the Extreme N-Terminus of MHC Class II Transactivator CIITA Isoform III. PLoS ONE 2016, 11, e0148753. [CrossRef]

37. Greer, S.F.; Zika, E.; Conti, B.; Zhu, X.S.; Ting, J.P. Enhancement of CIITA transcriptional function by ubiquitin. Nat. Immunol. 2003, 4, 1074-1082. [CrossRef]

38. Meissner, T.B.; Li, A.; Biswas, A.; Lee, K.H.; Liu, Y.J.; Bayir, E.; Iliopoulos, D.; van den Elsen, P.J.; Kobayashi, K.S. NLR family member NLRC5 is a transcriptional regulator of MHC class I genes. Proc. Natl. Acad. Sci. USA 2010, 107, 13794-13799. [CrossRef]

39. Meissner, T.B.; Liu, Y.J.; Lee, K.H.; Li, A.; Biswas, A.; van Eggermond, M.C.; van den Elsen, P.J.; Kobayashi, K.S. NLRC5 cooperates with the RFX transcription factor complex to induce MHC class I gene expression. J. Immunol. 2012, 188, 4951-4958. [CrossRef]

40. Neerincx, A.; Rodriguez, G.M.; Steimle, V.; Kufer, T.A. NLRC5 controls basal MHC class I gene expression in an MHC enhanceosome-dependent manner. J. Immunol. 2012, 188, 4940-4950. [CrossRef]

41. Neerincx, A.; Castro, W.; Guarda, G.; Kufer, T.A. NLRC5, at the Heart of Antigen Presentation. Front. Immunol. 2013,4 , 397. [CrossRef]

42. Gutte, P.G.; Jurt, S.; Grutter, M.G.; Zerbe, O. Unusual structural features revealed by the solution NMR structure of the NLRC5 caspase recruitment domain. Biochemistry 2014, 53, 3106-3117. [CrossRef]

43. Neerincx, A.; Jakobshagen, K.; Utermohlen, O.; Buning, H.; Steimle, V.; Kufer, T.A. The N-terminal domain of NLRC5 confers transcriptional activity for MHC class I and II gene expression. J. Immunol. 2014, 193, 3090-3100. [CrossRef]

44. Staehli, F.; Ludigs, K.; Heinz, L.X.; Seguin-Estevez, Q.; Ferrero, I.; Braun, M.; Schroder, K.; Rebsamen, M.; Tardivel, A.; Mattmann, C.; et al. NLRC5 deficiency selectively impairs MHC class I- dependent lymphocyte killing by cytotoxic T cells. J. Immunol. 2012, 188, 3820-3828. [CrossRef]

45. Biswas, A.; Meissner, T.B.; Kawai, T.; Kobayashi, K.S. Cutting edge: Impaired MHC class I expression in mice deficient for Nlrc5/class I transactivator. J. Immunol. 2012, 189, 516-520. [CrossRef]

46. Yao, Y.; Wang, Y.; Chen, F.; Huang, Y.; Zhu, S.; Leng, Q.; Wang, H.; Shi, Y.; Qian, Y. NLRC5 regulates MHC class I antigen presentation in host defense against intracellular pathogens. Cell Res. 2012, 22, 836-847. [CrossRef]

47. Steimle, V.; Durand, B.; Barras, E.; Zufferey, M.; Hadam, M.R.; Mach, B.; Reith, W. A novel DNA-binding regulatory factor is mutated in primary MHC class II deficiency (bare lymphocyte syndrome). Genes Dev. 1995, 9, 1021-1032. [CrossRef]

48. Durand, B.; Sperisen, P.; Emery, P.; Barras, E.; Zufferey, M.; Mach, B.; Reith, W. RFXAP, a novel subunit of the RFX DNA binding complex is mutated in MHC class II deficiency. EMBO J. 1997, 16, 1045-1055. [CrossRef]

49. Masternak, K.; Barras, E.; Zufferey, M.; Conrad, B.; Corthals, G.; Aebersold, R.; Sanchez, J.C.; Hochstrasser, D.F.; Mach, B.; Reith, W. A gene encoding a novel RFX-associated transactivator is mutated in the majority of MHC class II deficiency patients. Nat. Genet. 1998, 20, 273-277. [CrossRef]

50. Nagarajan, U.M.; Louis-Plence, P.; DeSandro, A.; Nilsen, R.; Bushey, A.; Boss, J.M. RFX-B is the gene responsible for the most common cause of the bare lymphocyte syndrome, an MHC class II immunodeficiency. Immunity 1999, 10, 153-162. [CrossRef]

51. Moreno, C.S.; Beresford, G.W.; Louis-Plence, P.; Morris, A.C.; Boss, J.M. CREB regulates MHC class II expression in a CIITAdependent manner. Immunity 1999, 10, 143-151. [CrossRef]

52. Dorn, A.; Bollekens, J.; Staub, A.; Benoist, C.; Mathis, D. A multiplicity of CCAAT box-binding proteins. Cell 1987, 50, 863-872. [CrossRef]

53. Sachini, N.; Papamatheakis, J. NF-Y and the immune response: Dissecting the complex regulation of MHC genes. Biochim. Biophys. Acta Gene Regul. Mech. 2017, 1860, 537-542. [CrossRef]

54. Scholl, T.; Mahanta, S.K.; Strominger, J.L. Specific complex formation between the type II bare lymphocyte syndrome-associated transactivators CIITA and RFX5. Proc. Natl. Acad. Sci. USA 1997, 94, 6330-6334. [CrossRef] [PubMed]

55. DeSandro, A.M.; Nagarajan, U.M.; Boss, J.M. Associations and interactions between bare lymphocyte syndrome factors. Mol. Cell. Biol. 2000, 20, 6587-6599. [CrossRef] 
56. Zhu, X.S.; Linhoff, M.W.; Li, G.; Chin, K.C.; Maity, S.N.; Ting, J.P. Transcriptional scaffold: CIITA interacts with NF-Y, RFX, and CREB to cause stereospecific regulation of the class II major histocompatibility complex promoter. Mol. Cell. Biol. 2000, 20, 6051-6061. [CrossRef]

57. Masternak, K.; Muhlethaler-Mottet, A.; Villard, J.; Zufferey, M.; Steimle, V.; Reith, W. CIITA is a transcriptional coactivator that is recruited to MHC class II promoters by multiple synergistic interactions with an enhanceosome complex. Genes Dev. 2000, 14, 1156-1166.

58. Rodriguez-Gil, A.; Ritter, O.; Saul, V.V.; Wilhelm, J.; Yang, C.Y.; Grosschedl, R.; Imai, Y.; Kuba, K.; Kracht, M.; Schmitz, M.L. The CCR4-NOT complex contributes to repression of Major Histocompatibility Complex class II transcription. Sci. Rep. $2017,7,3547$. [CrossRef]

59. Rybtsova, N.; Leimgruber, E.; Seguin-Estevez, Q.; Dunand-Sauthier, I.; Krawczyk, M.; Reith, W. Transcription-coupled deposition of histone modifications during MHC class II gene activation. Nucleic Acids Res. 2007, 35, 3431-3441. [CrossRef]

60. Leimgruber, E.; Seguin-Estevez, Q.; Dunand-Sauthier, I.; Rybtsova, N.; Schmid, C.D.; Ambrosini, G.; Bucher, P.; Reith, W. Nucleosome eviction from MHC class II promoters controls positioning of the transcription start site. Nucleic Acids Res. 2009, 37, 2514-2528. [CrossRef]

61. Krawczyk, M.; Peyraud, N.; Rybtsova, N.; Masternak, K.; Bucher, P.; Barras, E.; Reith, W. Long distance control of MHC class II expression by multiple distal enhancers regulated by regulatory factor X complex and CIITA. J. Immunol. 2004, 173, 6200-6210. [CrossRef] [PubMed]

62. Gomez, J.A.; Majumder, P.; Nagarajan, U.M.; Boss, J.M. X box-like sequences in the MHC class II region maintain regulatory function. J. Immunol. 2005, 175, 1030-1040. [CrossRef] [PubMed]

63. Majumder, P.; Gomez, J.A.; Chadwick, B.P.; Boss, J.M. The insulator factor CTCF controls MHC class II gene expression and is required for the formation of long-distance chromatin interactions. J. Exp. Med. 2008, 205, 785-798. [CrossRef]

64. Majumder, P.; Boss, J.M. CTCF controls expression and chromatin architecture of the human major histocompatibility complex class II locus. Mol. Cell. Biol. 2010, 30, 4211-4223. [CrossRef]

65. Cavalli, G.; Hayashi, M.; Jin, Y.; Yorgov, D.; Santorico, S.A.; Holcomb, C.; Rastrou, M.; Erlich, H.; Tengesdal, I.W.; Dagna, L.; et al. MHC class II super-enhancer increases surface expression of HLA-DR and HLA-DQ and affects cytokine production in autoimmune vitiligo. Proc. Natl. Acad. Sci. USA 2016, 113, 1363-1368. [CrossRef]

66. Majumder, P.; Lee, J.T.; Rahmberg, A.R.; Kumar, G.; Mi, T.; Scharer, C.D.; Boss, J.M. A super enhancer controls expression and chromatin architecture within the MHC class II locus. J. Exp. Med. 2020, 217, e20190668. [CrossRef]

67. Martin, B.K.; Chin, K.C.; Olsen, J.C.; Skinner, C.A.; Dey, A.; Ozato, K.; Ting, J.P. Induction of MHC class I expression by the MHC class II transactivator CIITA. Immunity 1997, 6, 591-600. [CrossRef]

68. Gobin, S.J.; Peijnenburg, A.; Keijsers, V.; van den Elsen, P.J. Site alpha is crucial for two routes of IFN gamma-induced MHC class I transactivation: The ISRE-mediated route and a novel pathway involving CIITA. Immunity 1997, 6, 601-611. [CrossRef]

69. Gobin, S.J.; Peijnenburg, A.; van Eggermond, M.; van Zutphen, M.; van den Berg, R.; van den Elsen, P.J. The RFX complex is crucial for the constitutive and CIITA-mediated transactivation of MHC class I and beta2-microglobulin genes. Immunity 1998, 9 , 531-541. [CrossRef]

70. Krawczyk, M.; Seguin-Estevez, Q.; Leimgruber, E.; Sperisen, P.; Schmid, C.; Bucher, P.; Reith, W. Identification of CIITA regulated genetic module dedicated for antigen presentation. PLoS Genet. 2008, 4, e1000058. [CrossRef]

71. Wong, D.; Lee, W.; Humburg, P.; Makino, S.; Lau, E.; Naranbhai, V.; Fairfax, B.P.; Chan, K.; Plant, K.; Knight, J.C. Genomic mapping of the MHC transactivator CIITA using an integrated ChIP-seq and genetical genomics approach. Genome Biol. 2014, 15, 494. [CrossRef] [PubMed]

72. Scharer, C.D.; Choi, N.M.; Barwick, B.G.; Majumder, P.; Lohsen, S.; Boss, J.M. Genome-wide CIITA-binding profile identifies sequence preferences that dictate function versus recruitment. Nucleic Acids Res. 2015, 43, 3128-3142. [CrossRef] [PubMed]

73. Ludigs, K.; Seguin-Estevez, Q.; Lemeille, S.; Ferrero, I.; Rota, G.; Chelbi, S.; Mattmann, C.; MacDonald, H.R.; Reith, W.; Guarda, G. NLRC5 exclusively transactivates MHC class I and related genes through a distinctive SXY module. PLoS Genet. 2015, 11, e1005088. [CrossRef] [PubMed]

74. LeibundGut-Landmann, S.; Waldburger, J.M.; Krawczyk, M.; Otten, L.A.; Suter, T.; Fontana, A.; Acha-Orbea, H.; Reith, W. Mini-review: Specificity and expression of CIITA, the master regulator of MHC class II genes. Eur. J. Immunol. 2004, 34, 1513-1525. [CrossRef] [PubMed]

75. Waldburger, J.M.; Suter, T.; Fontana, A.; Acha-Orbea, H.; Reith, W. Selective abrogation of major histocompatibility complex class II expression on extrahematopoietic cells in mice lacking promoter IV of the class II transactivator gene. J. Exp. Med. 2001, 194, 393-406. [CrossRef]

76. Waldburger, J.M.; Rossi, S.; Hollander, G.A.; Rodewald, H.R.; Reith, W.; Acha-Orbea, H. Promoter IV of the class II transactivator gene is essential for positive selection of CD4+ T cells. Blood 2003, 101, 3550-3559. [CrossRef]

77. LeibundGut-Landmann, S.; Waldburger, J.M.; Reis e Sousa, C.; Acha-Orbea, H.; Reith, W. MHC class II expression is differentially regulated in plasmacytoid and conventional dendritic cells. Nat. Immunol. 2004, 5, 899-908. [CrossRef]

78. Colonna, M.; Trinchieri, G.; Liu, Y.J. Plasmacytoid dendritic cells in immunity. Nat. Immunol. 2004, 5, 1219-1226. [CrossRef]

79. Holling, T.M.; van der Stoep, N.; Quinten, E.; van den Elsen, P.J. Activated human T cells accomplish MHC class II expression through T cell-specific occupation of class II transactivator promoter III. J. Immunol. 2002, 168, 763-770. [CrossRef] 
80. Muhlethaler-Mottet, A.; Otten, L.A.; Steimle, V.; Mach, B. Expression of MHC class II molecules in different cellular and functional compartments is controlled by differential usage of multiple promoters of the transactivator CIITA. EMBO J. 1997, 16, 2851-2860. [CrossRef]

81. Zinzow-Kramer, W.M.; Long, A.B.; Youngblood, B.A.; Rosenthal, K.M.; Butler, R.; Mohammed, A.U.; Skountzou, I.; Ahmed, R.; Evavold, B.D.; Boss, J.M. CIITA promoter I CARD-deficient mice express functional MHC class II genes in myeloid and lymphoid compartments. Genes Immun. 2012, 13, 299-310. [CrossRef]

82. Lohsen, S.; Majumder, P.; Scharer, C.D.; Barwick, B.G.; Austin, J.W.; Zinzow-Kramer, W.M.; Boss, J.M. Common distal elements orchestrate CIITA isoform-specific expression in multiple cell types. Genes Immun. 2014, 15, 543-555. [CrossRef]

83. Ni, Z.; Abou El Hassan, M.; Xu, Z.; Yu, T.; Bremner, R. The chromatin-remodeling enzyme BRG1 coordinates CIITA induction through many interdependent distal enhancers. Nat. Immunol. 2008, 9, 785-793. [CrossRef]

84. Abou El Hassan, M.; Yu, T.; Song, L.; Bremner, R. Polycomb Repressive Complex 2 Confers BRG1 Dependency on the CIITA Locus. J. Immunol. 2015, 194, 5007-5013. [CrossRef]

85. Buxade, M.; Huerga Encabo, H.; Riera-Borrull, M.; Quintana-Gallardo, L.; Lopez-Cotarelo, P.; Tellechea, M.; Martinez-Martinez, S.; Redondo, J.M.; Martin-Caballero, J.; Flores, J.M.; et al. Macrophage-specific MHCII expression is regulated by a remote Ciita enhancer controlled by NFAT5. J. Exp. Med. 2018, 215, 2901-2918. [CrossRef]

86. Okamoto, H.; Asamitsu, K.; Nishimura, H.; Kamatani, N.; Okamoto, T. Reciprocal modulation of transcriptional activities between HIV-1 Tat and MHC class II transactivator CIITA. Biochem. Biophys. Res. Commun. 2000, 279, 494-499. [CrossRef]

87. Kanazawa, S.; Okamoto, T.; Peterlin, B.M. Tat competes with CIITA for the binding to P-TEFb and blocks the expression of MHC class II genes in HIV infection. Immunity 2000, 12, 61-70. [CrossRef]

88. Stumptner-Cuvelette, P.; Morchoisne, S.; Dugast, M.; Le Gall, S.; Raposo, G.; Schwartz, O.; Benaroch, P. HIV-1 Nef impairs MHC class II antigen presentation and surface expression. Proc. Natl. Acad. Sci. USA 2001, 98, 12144-12149. [CrossRef]

89. Mudhasani, R.; Fontes, J.D. Inhibition of class II trans-activator function by HIV-1 tat in mouse cells is independent of competition for binding to cyclin T1. Mol. Immunol. 2002, 38, 539-546. [CrossRef]

90. Abendroth, A.; Slobedman, B.; Lee, E.; Mellins, E.; Wallace, M.; Arvin, A.M. Modulation of major histocompatibility class II protein expression by varicella-zoster virus. J. Virol. 2000, 74, 1900-1907. [CrossRef]

91. Verweij, M.C.; Wellish, M.; Whitmer, T.; Malouli, D.; Lapel, M.; Jonjic, S.; Haas, J.G.; DeFilippis, V.R.; Mahalingam, R.; Fruh, K. Varicella Viruses Inhibit Interferon-Stimulated JAK-STAT Signaling through Multiple Mechanisms. PLoS. Pathog. 2015, 11, e1004901. [CrossRef] [PubMed]

92. Le Roy, E.; Muhlethaler-Mottet, A.; Davrinche, C.; Mach, B.; Davignon, J.L. Escape of human cytomegalovirus from HLA-DRrestricted CD4(+) T-cell response is mediated by repression of gamma interferon-induced class II transactivator expression. J. Virol. 1999, 73, 6582-6589. [CrossRef]

93. Lin, J.H.; Lin, J.Y.; Chou, Y.C.; Chen, M.R.; Yeh, T.H.; Lin, C.W.; Lin, S.J.; Tsai, C.H. Epstein-Barr virus LMP2A suppresses MHC class II expression by regulating the B-cell transcription factors E47 and PU.1. Blood 2015, 125, 2228-2238. [CrossRef]

94. Lee, A.W.; Wang, N.; Hornell, T.M.; Harding, J.J.; Deshpande, C.; Hertel, L.; Lacaille, V.; Pashine, A.; Macaubas, C.; Mocarski, E.S.; et al. Human cytomegalovirus decreases constitutive transcription of MHC class II genes in mature Langerhans cells by reducing CIITA transcript levels. Mol. Immunol. 2011, 48, 1160-1167. [CrossRef]

95. Sandhu, P.K.; Buchkovich, N.J. Human Cytomegalovirus Decreases Major Histocompatibility Complex Class II by Regulating Class II Transactivator Transcript Levels in a Myeloid Cell Line. J. Virol. 2020, 94. [CrossRef]

96. Gao, J.; De, B.P.; Han, Y.; Choudhary, S.; Ransohoff, R.; Banerjee, A.K. Human parainfluenza virus type 3 inhibits gamma interferon-induced major histocompatibility complex class II expression directly and by inducing alpha/beta interferon. J. Virol. 2001, 75, 1124-1131. [CrossRef]

97. Uetani, K.; Hiroi, M.; Meguro, T.; Ogawa, H.; Kamisako, T.; Ohmori, Y.; Erzurum, S.C. Influenza A virus abrogates IFN-gamma response in respiratory epithelial cells by disruption of the Jak/Stat pathway. Eur. J. Immunol. 2008, 38, 1559-1573. [CrossRef]

98. Zuo, J.; Rowe, M. Herpesviruses placating the unwilling host: Manipulation of the MHC class II antigen presentation pathway. Viruses 2012, 4, 1335-1353. [CrossRef]

99. Zuo, J.; Hislop, A.D.; Leung, C.S.; Sabbah, S.; Rowe, M. Kaposi's sarcoma-associated herpesvirus-encoded viral IRF3 modulates major histocompatibility complex class II (MHC-II) antigen presentation through MHC-II transactivator-dependent and independent mechanisms: Implications for oncogenesis. J. Virol. 2013, 87, 5340-5350. [CrossRef]

100. Butler, L.M.; Jeffery, H.C.; Wheat, R.L.; Long, H.M.; Rae, P.C.; Nash, G.B.; Blackbourn, D.J. Kaposi's sarcoma-associated herpesvirus inhibits expression and function of endothelial cell major histocompatibility complex class II via suppressor of cytokine signaling 3. J. Virol. 2012, 86, 7158-7166. [CrossRef]

101. Luder, C.G.; Lang, C.; Giraldo-Velasquez, M.; Algner, M.; Gerdes, J.; Gross, U. Toxoplasma gondii inhibits MHC class II expression in neural antigen-presenting cells by down-regulating the class II transactivator CIITA. J. Neuroimmunol. 2003, 134, 12-24. [CrossRef]

102. Lang, C.; Algner, M.; Beinert, N.; Gross, U.; Luder, C.G. Diverse mechanisms employed by Toxoplasma gondii to inhibit IFN-gamma-induced major histocompatibility complex class II gene expression. Microbes Infect. 2006, 8, 1994-2005. [CrossRef] [PubMed] 
103. Leroux, L.P.; Dasanayake, D.; Rommereim, L.M.; Fox, B.A.; Bzik, D.J.; Jardim, A.; Dzierszinski, F.S. Secreted Toxoplasma gondii molecules interfere with expression of MHC-II in interferon gamma-activated macrophages. Int. J. Parasitol. 2015, 45, 319-332. [CrossRef] [PubMed]

104. Wojciechowski, W.; DeSanctis, J.; Skamene, E.; Radzioch, D. Attenuation of MHC class II expression in macrophages infected with Mycobacterium bovis bacillus Calmette-Guerin involves class II transactivator and depends on the Nramp1 gene. J. Immunol. 1999, 163, 2688-2696.

105. Pai, R.K.; Convery, M.; Hamilton, T.A.; Boom, W.H.; Harding, C.V. Inhibition of IFN-gamma-induced class II transactivator expression by a 19-kDa lipoprotein from Mycobacterium tuberculosis: A potential mechanism for immune evasion. J. Immunol. 2003, 171, 175-184. [CrossRef]

106. Pennini, M.E.; Pai, R.K.; Schultz, D.C.; Boom, W.H.; Harding, C.V. Mycobacterium tuberculosis 19-kDa lipoprotein inhibits IFN-gamma-induced chromatin remodeling of MHC2TA by TLR2 and MAPK signaling. J Immunol. 2006, 176, 4323-4330. [CrossRef]

107. Zhong, G.; Fan, T.; Liu, L. Chlamydia inhibits interferon gamma-inducible major histocompatibility complex class II expression by degradation of upstream stimulatory factor 1. J. Exp. Med. 1999, 189, 1931-1938. [CrossRef]

108. Peschel, G.; Kernschmidt, L.; Cirl, C.; Wantia, N.; Ertl, T.; Durr, S.; Wagner, H.; Miethke, T.; Rodriguez, N. Chlamydophila pneumoniae downregulates MHC-class II expression by two cell type-specific mechanisms. Mol. Microbiol. 2010, 76, 648-661. [CrossRef]

109. Tortorella, D.; Gewurz, B.; Schust, D.; Furman, M.; Ploegh, H. Down-regulation of MHC class I antigen presentation by HCMV; lessons for tumor immunology. Immunol. Investig. 2000, 29, 97-100. [CrossRef]

110. Tortorella, D.; Gewurz, B.E.; Furman, M.H.; Schust, D.J.; Ploegh, H.L. Viral subversion of the immune system. Annu. Rev. Immunol. 2000, 18, 861-926. [CrossRef]

111. Li, D.; Qian, L.; Chen, C.; Shi, M.; Yu, M.; Hu, M.; Song, L.; Shen, B.; Guo, N. Down-regulation of MHC class II expression through inhibition of CIITA transcription by lytic transactivator Zta during Epstein-Barr virus reactivation. J. Immunol. 2009, 182, 1799-1809. [CrossRef]

112. Wong, A.W.; Brickey, W.J.; Taxman, D.J.; van Deventer, H.W.; Reed, W.; Gao, J.X.; Zheng, P.; Liu, Y.; Li, P.; Blum, J.S.; et al. CIITA-regulated plexin-A1 affects T-cell-dendritic cell interactions. Nat. Immunol. 2003, 4, 891-898. [CrossRef]

113. Krawczyk, M.; Leimgruber, E.; Seguin-Estevez, Q.; Dunand-Sauthier, I.; Barras, E.; Reith, W. Expression of RAB4B, a protein governing endocytic recycling, is co-regulated with MHC class II genes. Nucleic Acids Res. 2007, 35, 595-605. [CrossRef] [PubMed]

114. Sarter, K.; Leimgruber, E.; Gobet, F.; Agrawal, V.; Dunand-Sauthier, I.; Barras, E.; Mastelic-Gavillet, B.; Kamath, A.; Fontannaz, P.; Guery, L.; et al. Btn2a2, a T cell immunomodulatory molecule coregulated with MHC class II genes. J. Exp. Med. 2016, 213, 177-187. [CrossRef] [PubMed]

115. Xu, Y.; Wang, L.; Buttice, G.; Sengupta, P.K.; Smith, B.D. Interferon gamma repression of collagen (COL1A2) transcription is mediated by the RFX5 complex. J. Biol. Chem. 2003, 278, 49134-49144. [CrossRef] [PubMed]

116. Xu, Y.; Wang, L.; Buttice, G.; Sengupta, P.K.; Smith, B.D. Major histocompatibility class II transactivator (CIITA) mediates repression of collagen (COL1A2) transcription by interferon gamma (IFN-gamma). J. Biol. Chem. 2004, 279, 41319-41332. [CrossRef]

117. Sengupta, P.; Xu, Y.; Wang, L.; Widom, R.; Smith, B.D. Collagen alpha1(I) gene (COL1A1) is repressed by RFX family. J. Biol. Chem. 2005, 280, 21004-21014. [CrossRef] [PubMed]

118. Xu, Y.; Sengupta, P.K.; Seto, E.; Smith, B.D. Regulatory factor for X-box family proteins differentially interact with histone deacetylases to repress collagen alpha2(I) gene (COL1A2) expression. J. Biol. Chem. 2006, 281, 9260-9270. [CrossRef]

119. Xu, Y.; McDonald, J.; Perloff, E.; Buttice, G.; Schreiber, B.M.; Smith, B.D. Collagen and major histocompatibility class II expression in mesenchymal cells from CIITA hypomorphic mice. Mol. Immunol. 2007, 44, 1709-1721. [CrossRef]

120. Xu, Y.; Harton, J.A.; Smith, B.D. CIITA mediates interferon-gamma repression of collagen transcription through phosphorylationdependent interactions with co-repressor molecules. J. Biol. Chem. 2008, 283, 1243-1256. [CrossRef]

121. Weng, X.; Zhang, Y.; Li, Z.; Yu, L.; Xu, F.; Fang, M.; Hou, L.; Ge, J.; Xu, Y. Class II transactivator (CIITA) mediates IFN-gamma induced eNOS repression by enlisting SUV39H1. Biochim. Biophys. Acta Gene Regul. Mech. 2019, 1862, 163-172. [CrossRef] [PubMed]

122. Otten, L.A.; Leibundgut-Landmann, S.; Huarte, J.; Kos-Braun, I.C.; Lavanchy, C.; Barras, E.; Borisch, B.; Steimle, V.; Acha-Orbea, H.; Reith, W. Revisiting the specificity of the MHC class II transactivator CIITA in vivo. Eur. J. Immunol. 2006, 36, 1548-1558. [CrossRef] [PubMed]

123. Bruchard, M.; Rebe, C.; Derangere, V.; Togbe, D.; Ryffel, B.; Boidot, R.; Humblin, E.; Hamman, A.; Chalmin, F.; Berger, H.; et al. The receptor NLRP3 is a transcriptional regulator of TH2 differentiation. Nat. Immunol. 2015, 16, 859-870. [CrossRef] [PubMed]

124. Ting, J.P.; Harton, J.A. NLRP3 moonlights in TH2 polarization. Nat. Immunol. 2015, 16, 794-796. [CrossRef]

125. Liu, Y.; Gao, X.; Miao, Y.; Wang, Y.; Wang, H.; Cheng, Z.; Wang, X.; Jing, X.; Jia, L.; Dai, L.; et al. NLRP3 regulates macrophage M2 polarization through up-regulation of IL-4 in asthma. Biochem. J. 2018, 475, 1995-2008. [CrossRef]

126. Campo, E.; Swerdlow, S.H.; Harris, N.L.; Pileri, S.; Stein, H.; Jaffe, E.S. The 2008 WHO classification of lymphoid neoplasms and beyond: Evolving concepts and practical applications. Blood 2011, 117, 5019-5032. [CrossRef] 
127. Mottok, A.; Woolcock, B.; Chan, F.C.; Tong, K.M.; Chong, L.; Farinha, P.; Telenius, A.; Chavez, E.; Ramchandani, S.; Drake, M.; et al. Genomic Alterations in CIITA Are Frequent in Primary Mediastinal Large B Cell Lymphoma and Are Associated with Diminished MHC Class II Expression. Cell Rep. 2015, 13, 1418-1431. [CrossRef]

128. Gunawardana, J.; Chan, F.C.; Telenius, A.; Woolcock, B.; Kridel, R.; Tan, K.L.; Ben-Neriah, S.; Mottok, A.; Lim, R.S.; Boyle, M.; et al. Recurrent somatic mutations of PTPN1 in primary mediastinal B cell lymphoma and Hodgkin lymphoma. Nat. Genet. 2014, 46, 329-335. [CrossRef]

129. Yuan, J.; Wright, G.; Rosenwald, A.; Steidl, C.; Gascoyne, R.D.; Connors, J.M.; Mottok, A.; Weisenburger, D.D.; Greiner, T.C.; Fu, K.; et al. Identification of Primary Mediastinal Large B-cell Lymphoma at Nonmediastinal Sites by Gene Expression Profiling. Am. J. Surg. Pathol. 2015, 39, 1322-1330. [CrossRef]

130. Mottok, A.; Hung, S.S.; Chavez, E.A.; Woolcock, B.; Telenius, A.; Chong, L.C.; Meissner, B.; Nakamura, H.; Rushton, C.; Vigano, E.; et al. Integrative genomic analysis identifies key pathogenic mechanisms in primary mediastinal large B-cell lymphoma. Blood 2019, 134, 802-813. [CrossRef]

131. Zhou, X.A.; Louissaint, A., Jr.; Wenzel, A.; Yang, J.; Martinez-Escala, M.E.; Moy, A.P.; Morgan, E.A.; Paxton, C.N.; Hong, B.; Andersen, E.F.; et al. Genomic Analyses Identify Recurrent Alterations in Immune Evasion Genes in Diffuse Large B-Cell Lymphoma, Leg Type. J. Investig. Derm. 2018, 138, 2365-2376. [CrossRef] [PubMed]

132. Mareschal, S.; Pham-Ledard, A.; Viailly, P.J.; Dubois, S.; Bertrand, P.; Maingonnat, C.; Fontanilles, M.; Bohers, E.; Ruminy, P.; Tournier, I.; et al. Identification of Somatic Mutations in Primary Cutaneous Diffuse Large B-Cell Lymphoma, Leg Type by Massive Parallel Sequencing. J. Investig. Derm. 2017, 137, 1984-1994. [CrossRef] [PubMed]

133. Brown, P.J.; Wong, K.K.; Felce, S.L.; Lyne, L.; Spearman, H.; Soilleux, E.J.; Pedersen, L.M.; Moller, M.B.; Green, T.M.; Gascoyne, D.M.; et al. FOXP1 suppresses immune response signatures and MHC class II expression in activated B-cell-like diffuse large B-cell lymphomas. Leukemia 2016, 30, 605-616. [CrossRef] [PubMed]

134. Jiao, F.; Li, Z.; He, C.; Xu, W.; Yang, G.; Liu, T.; Shen, H.; Cai, J.; Anastas, J.N.; Mao, Y.; et al. RACK7 recognizes H3.3G34R mutation to suppress expression of MHC class II complex components and their delivery pathway in pediatric glioblastoma. Sci. Adv. 2020, 6, eaba2113. [CrossRef] [PubMed]

135. Tarafdar, A.; Hopcroft, L.E.; Gallipoli, P.; Pellicano, F.; Cassels, J.; Hair, A.; Korfi, K.; Jorgensen, H.G.; Vetrie, D.; Holyoake, T.L.; et al. CML cells actively evade host immune surveillance through cytokine-mediated downregulation of MHC-II expression. Blood 2017, 129, 199-208. [CrossRef]

136. Toffalori, C.; Zito, L.; Gambacorta, V.; Riba, M.; Oliveira, G.; Bucci, G.; Barcella, M.; Spinelli, O.; Greco, R.; Crucitti, L.; et al. Immune signature drives leukemia escape and relapse after hematopoietic cell transplantation. Nat. Med. 2019, 25, 603-611. [CrossRef]

137. Ghasemi, F.; Tessier, T.M.; Gameiro, S.F.; Maciver, A.H.; Cecchini, M.J.; Mymryk, J.S. High MHC-II expression in Epstein-Barr virus-associated gastric cancers suggests that tumor cells serve an important role in antigen presentation. Sci. Rep. 2020, 10, 14786. [CrossRef]

138. Zuo, J.; Thomas, W.A.; Haigh, T.A.; Fitzsimmons, L.; Long, H.M.; Hislop, A.D.; Taylor, G.S.; Rowe, M. Epstein-Barr virus evades CD4+ T cell responses in lytic cycle through BZLF1-mediated downregulation of CD74 and the cooperation of vBcl-2. PLoS Pathog. 2011, 7, e1002455. [CrossRef]

139. Gameiro, S.F.; Ghasemi, F.; Barrett, J.W.; Nichols, A.C.; Mymryk, J.S. High Level Expression of MHC-II in HPV+ Head and Neck Cancers Suggests that Tumor Epithelial Cells Serve an Important Role as Accessory Antigen Presenting Cells. Cancers 2019, 11, 1129. [CrossRef]

140. Bou Nasser Eddine, F.; Forlani, G.; Lombardo, L.; Tedeschi, A.; Tosi, G.; Accolla, R.S. CIITA-driven MHC class II expressing tumor cells can efficiently prime naive CD4(+) TH cells in vivo and vaccinate the host against parental MHC-II-negative tumor cells. Oncoimmunology 2017, 6, e1261777. [CrossRef]

141. Accolla, R.S.; Ramia, E.; Tedeschi, A.; Forlani, G. CIITA-Driven MHC Class II Expressing Tumor Cells as Antigen Presenting Cell Performers: Toward the Construction of an Optimal Anti-tumor Vaccine. Front. Immunol. 2019, 10, 1806. [CrossRef] [PubMed]

142. Singh-Jasuja, H.; Emmerich, N.P.; Rammensee, H.G. The Tubingen approach: Identification, selection, and validation of tumorassociated HLA peptides for cancer therapy. Cancer Immunol. Immunother. 2004, 53, 187-195. [CrossRef] [PubMed]

143. Johnson, A.M.; Bullock, B.L.; Neuwelt, A.J.; Poczobutt, J.M.; Kaspar, R.E.; Li, H.Y.; Kwak, J.W.; Hopp, K.; Weiser-Evans, M.C.M.; Heasley, L.E.; et al. Cancer Cell-Intrinsic Expression of MHC Class II Regulates the Immune Microenvironment and Response to Anti-PD-1 Therapy in Lung Adenocarcinoma. J. Immunol. 2020, 204, 2295-2307. [CrossRef] [PubMed]

144. Kobayashi, K.S. NLRC5/CITA: A novel regulator of class I major histocompatibility complex genes. J. Immunodefic. Disord. 2012, 1, 1000e102. [CrossRef] [PubMed]

145. Yoshihama, S.; Roszik, J.; Downs, I.; Meissner, T.B.; Vijayan, S.; Chapuy, B.; Sidiq, T.; Shipp, M.A.; Lizee, G.A.; Kobayashi, K.S. NLRC5/MHC class I transactivator is a target for immune evasion in cancer. Proc. Natl. Acad. Sci. USA 2016, 113, 5999-6004. [CrossRef]

146. Vijayan, S.; Sidiq, T.; Yousuf, S.; van den Elsen, P.J.; Kobayashi, K.S. Class I transactivator, NLRC5: A central player in the MHC class I pathway and cancer immune surveillance. Immunogenetics 2019, 71, 273-282. [CrossRef]

147. Rodriguez, G.M.; Bobbala, D.; Serrano, D.; Mayhue, M.; Champagne, A.; Saucier, C.; Steimle, V.; Kufer, T.A.; Menendez, A.; Ramanathan, S.; et al. NLRC5 elicits antitumor immunity by enhancing processing and presentation of tumor antigens to CD8(+) T lymphocytes. Oncoimmunology 2016, 5, e1151593. [CrossRef] 
148. Yan, N.; Chen, Z.J. Intrinsic antiviral immunity. Nat. Immunol. 2012, 13, 214-222. [CrossRef]

149. Accolla, R.S.; De Lerma Barbaro, A.; Mazza, S.; Casoli, C.; De Maria, A.; Tosi, G. The MHC class II transactivator: Prey and hunter in infectious diseases. Trends Immunol. 2001, 22, 560-563. [CrossRef]

150. Tosi, G.; Forlani, G.; Andresen, V.; Turci, M.; Bertazzoni, U.; Franchini, G.; Poli, G.; Accolla, R.S. Major histocompatibility complex class II transactivator CIITA is a viral restriction factor that targets human T-cell lymphotropic virus type 1 Tax-1 function and inhibits viral replication. J. Virol. 2011, 85, 10719-10729. [CrossRef]

151. Forlani, G.; Shallak, M.; Ramia, E.; Tedeschi, A.; Accolla, R.S. Restriction factors in human retrovirus infections and the unprecedented case of CIITA as link of intrinsic and adaptive immunity against HTLV-1. Retrovirology 2019, 16, 34. [CrossRef] [PubMed]

152. Forlani, G.; Turrini, F.; Ghezzi, S.; Tedeschi, A.; Poli, G.; Accolla, R.S.; Tosi, G. The MHC-II transactivator CIITA inhibits Tat function and HIV-1 replication in human myeloid cells. J. Transl. Med. 2016, 14, 94. [CrossRef] [PubMed]

153. Forlani, G.; Abdallah, R.; Accolla, R.S.; Tosi, G. The Major Histocompatibility Complex Class II Transactivator CIITA Inhibits the Persistent Activation of NF-kappaB by the Human T Cell Lymphotropic Virus Type 1 Tax-1 Oncoprotein. J. Virol. 2016, 90, 3708-3721. [CrossRef] [PubMed]

154. Tissot, C.; Mechti, N. Molecular cloning of a new interferon-induced factor that represses human immunodeficiency virus type 1 long terminal repeat expression. J. Biol. Chem. 1995, 270, 14891-14898. [CrossRef]

155. Forlani, G.; Tosi, G.; Turrini, F.; Poli, G.; Vicenzi, E.; Accolla, R.S. Tripartite Motif-Containing Protein 22 Interacts with Class II Transactivator and Orchestrates Its Recruitment in Nuclear Bodies Containing TRIM19/PML and Cyclin T1. Front. Immunol. 2017, 8, 564. [CrossRef]

156. Tosi, G.; Pilotti, E.; Mortara, L.; De Lerma Barbaro, A.; Casoli, C.; Accolla, R.S. Inhibition of human T cell leukemia virus type 2 replication by the suppressive action of class II transactivator and nuclear factor Y. Proc. Natl. Acad. Sci. USA 2006, 103, 12861-12866. [CrossRef]

157. Bruchez, A.; Sha, K.; Johnson, J.; Chen, L.; Stefani, C.; McConnell, H.; Gaucherand, L.; Prins, R.; Matreyek, K.A.; Hume, A.J.; et al. MHC class II transactivator CIITA induces cell resistance to Ebola virus and SARS-like coronaviruses. Science 2020, 370, $241-247$. [CrossRef] 